\title{
Antifungal Activity Of Olea Cuspidata And Olea Gladulifera Linn.
}

\author{
${ }^{1,}$ Preeti Majgaine , ${ }^{2}$ D.L.V.Verma \\ ${ }^{1,2,}$ Department of Chemistry, Kumaun University, S.S.J. Campus, Almora
}

\begin{abstract}
The antifungal activity of dichloromethane extrct of Olea cuspidate and Olea glandulifera was investigated against Candida albicans and Aspergillus niger. The plants were extracted with dichloromethane and antifungal screening of this extract was done by disc diffusion method. Flavonoidal compounds were present in dichloromethane fraction and it is reported that flavonoidse responsible for antifungal activity. The diameters of inhibition zones were used as a measure of antifungal activity and resulting zone of inhibition was measured around the disc with transparent scale in millimeters.
\end{abstract}

KEY WORDS: Olea cuspidate, Olea glandulifera, Candida albicans and Aspergillus niger

\section{INTRODUCTION}

Olive tree (Olea europaea L.) is one of the most important fruit trees in Mediterranean countries, where they cover 8 million ha, accounting for almost $98 \%$ of the world crop (Pereira et. al, 2007). Historically, Olive leaf extract has been widely used in folk medicine for combating fever and other diseases such as malaria (Banavente- Garcia et. al., 2000). Olive leaf extract has the capacity of lower blood pressure in animals(Khayyal et. al., 2002) and increases blood flow in coronary arteries, relieves arrthythmia and prevents intestinal muscle spasms (Zarzuelo, 1991). Phenolic compounds isolated from Olive fruit have been shown to inhibit the growth of Eschesrichia coli, Klebslella pneumonia and Staphylococcus aureus( Aziz et. al., 1998; Yigit et.al., 2001).Gourama and Bullerman, (1987), tested the effect of oleuropein on growth and aflatoxin production by aspergillus parasiticus and found that Oleuropein stimulated mold growth but inhibit the production aflatoxin. Sousa et. al.(2006) reported that the determination of phenolic compounds in 'alcapurra' table olives and evalution of their extract in vitro activity against gram positive, gram negative bacteria and fungi(Candida albicans and Cryptococcus neoformans). Some aldehydes obtained from olive fruit revealed antifungal activity against Tricophyton mentagrophylus, Microsporum canis and candida Spp. (Battinelli et. al., 2006). Phenolic compounds within olive leaf extract have shown antimicrobial activities against several microorganisms including: Escherichia coli, Staphylococcus aureus, Klebsiella pneumoniae, Bacillus cereus, Salmonella typhi and Vibrio parahaemolyticu (Owen et. al., 2003).

Olea cuspidata is found in the Himalayas from Kashmir to Kumaun upto $2400 \mathrm{~m}$ altitude. According to Chopra et al, 1986 Olea glandulifera was distributed in N.W. Himalayas 2000-6000 ft. from Kashmir to Nepal, N. circars hills of ganjam and Vizagapatam, Deccan, Maysore and W. ghats of Madras State.Pathogenic fungi and bacteria cause different types of human diseases and shows adverse effect on human health. Skin, hair, nail and subcutaneous tissues in human and animal are subjected to infection by several organisms, mainly fungi named dermatophytoses( Valeria et. al., 1996; Amer et. al., 2006). As it is clear from the literature Olive have antifungal activity against disease causing fungi. Thus, the main objective of this study was to investigate antifungal activity of extracts from Olea cuspidata and Olea glandulifera species.

\section{MATERIALS AND METHODS:}

2.1.Collection of plant material: For antifungal screening plant material (Olea cuspidata) was collected from NCC ground Almora and Olea glandulifera was collected from Govind Ballabh Pant Institute of Himalayan Environment and Development,Koshi,Katarmal(Almora) .

2.2.Preparation of crude extract: The dried powdered leaves of plant material (Botanically identified) were extracted sequentially extracted with $50 \%$ aq. EtOH by Cold Percolation methods. The $\mathrm{H}_{2} \mathrm{O}-\mathrm{EtOH}$ extract was concentrated under reduced pressure at $40^{\circ} \mathrm{C}$ in Rota-evaporator until only $\mathrm{H}_{2} \mathrm{O}$ layer (approx. $50 \mathrm{ml}$.) remained the aqueous layer was partitioned successively with $\mathrm{CH}_{2} \mathrm{Cl}_{2}$. Dichloromethane extract with different concentration was examined for antifungal test by standard disc diffusion assay Murray et.al., 1995.

The undiluted plant extract was diluted, whether required in N.S.S. (Normal Saline Solution). The standard procedure suggested by Cruiskshank et al, 1975, was followed to make serial two fold dilution- 
[1] Five clear sterile cotton pluged test tubes of medium size were taken in duplicates and marked as 1-5.

[2] Using aspectic techniques, $5 \mathrm{ml}$ of NSS was taken into all five tubes.

[3] The first tube, $5 \mathrm{ml}$ solution $(200 \mathrm{gm} / \mathrm{ml})$ of the plant leaf extract was added ; contents of the tube were mixed properly by pipetting.

[4] From first tube, $5 \mathrm{ml}$ of suspension was transferred to second tube, mixed well and again $5 \mathrm{ml}$ suspension was transferred from second to the third tube.

[5] This process was continued up to tube number five and $5 \mathrm{ml}$ solution from the last tube was discarded. $\mathrm{tn}$ this way two series of two fold dilution was prepared, one serve as a test series and another serve as a parallel control. Thus, the dilution obtained were as 1:2, 1:4, 1:8, 1:16, 1:32. Same procedure was applied for Olea glandulifera and Olea pendolino.

TEST FUNGI: The antifungal activity plant extract was assessed against two fungi- Candida albicans and Aspergillus niger. The sources and details of culture are shown in the table No.-1

TABLE 1: DETAIL OF FUNGAL SOURCES PROCURED

\begin{tabular}{|l|l|l|l|}
\hline S.No. & Microbial Strain & Strain designation/Lab code & Source \\
\hline 1 & Candida albicans & MITC 183 & IMTECH Chandigarh \\
\hline 2 & Aspergillus niger & MITC 281 & IMTECH Chandigarh \\
\hline
\end{tabular}

2.3.Antifungal Assay (Disc Diffusion Method): Determination of antifungal activity of sample extracts was accomplished by agar disk diffusion method. The dried extracts were dissolved in NSS to a final concentration of two fold dilution of dichloromethane fraction. Antifungal tests were carried out using the disc diffusion method reported by (Murray et.al., 1995) and employing $100 \mu \mathrm{l}$ of suspension containing $104 \mathrm{spore} / \mathrm{ml}$ of (Candida albicans and Aspergillus flavus) on the Potato Dextrose Agar. PDA was autoclaved at $15 \mathrm{~b}$ pressure. PDA plates were allowed to solidify for 5 minutes and inoculums suspensions were transferred through strelized loop on PDA plates. The sterile disks $(10 \mathrm{~mm}$ in diameter) impregnated with $5 \mu \mathrm{l}$ of the extracts solution (equivalent to 12.5, 25, 50,100 and $200 \mathrm{mg} / \mathrm{disc}$ ) and NSS (as negative control) were placed on the inoculated agar. The inoculated plates were incubated for $72 \mathrm{~h}$ at $30^{\circ} \mathrm{C}$. The evalution of antifungal activity was carried out in triplets. The diameters of inhibition zones were used as a measure of antifungal activity and resulting zone of inhibition was measured around the disc with transparent scale in millimeters.

2.4.MINIUM INHIBITORY CONCENTRATION (MIC Assay): Minimum Inhibitory concentration of the positive extract was determined by the method suggested by Scott (1989). By this method, test organism were seeded uniformly over an agar surface and exposed to decreasing concentrations (200 mg/ml to $12.5 \mathrm{mg} / \mathrm{ml})$ of plant extract diffusing from paper disc (Disc diffusion Test). The plates were then incubated at $37^{\circ} \mathrm{C}$ for 18 hours. The fungi were sensitive to plant component they were inhibited from growing in a circular zone around the paper disc, Zone of inhibition was measured in $\mathrm{mm}$ with a "HI Antibiotic Zone Scale". Antifungal activity Olea cuspidata, against two fungal strain-Candida albicans and Aspergillus niger is summarized in the table No.-3(Fig-A and B)

\section{TABLE 2: MEAN INHIBITION ZONE DIAMETER OBTAINED BY LOADED DISC (Olea cuspidata) WITH $5 \mathrm{mg}$ EXTRACT DISSOLVED AGAINST DIFFERENT FUNGAL STRAIN}

\begin{tabular}{|l|l|l|l|l|}
\hline \multirow{2}{*}{$\begin{array}{l}\text { Different concentration of } \\
\text { plant extract(mg/l) }\end{array}$} & \multicolumn{4}{|c|}{ Test Fungi } \\
\cline { 2 - 5 } & Candida albicans & \multicolumn{4}{|l|}{ Aspergillus niger } \\
\cline { 2 - 5 } & Status & ZD(mm) SEM & Status & ZD(mm) SEM \\
\hline 200 & A & $26 \pm 1.632$ & A & 21.699 \\
\hline 100 & A & $18 \pm 1.699$ & A & A \\
\hline 50 & A & $12 \pm 0.816$ & N & 11.632 \\
\hline 25 & A & - & - & - \\
\hline 12.5 & - & & \\
\hline
\end{tabular}

Key to tables:

$\begin{array}{ll}\text { Symbole } & \text { Meaning } \\ \text { A } & \text { active } \\ \text { N } & \text { Non Active } \\ \text { ZD } & \text { Zone diameter } \\ (-) & \text { No effect } \\ \text { SEM } & \text { Standard error of Mean }\end{array}$


It is clear that, the plant extract shows antifungal assay when the concentration of dichloromethane was increased. It is also clear that plant extract have maximum antifungal activity against Candida albicans( nhibition zone $26 \mathrm{~mm}$ ) and Aspergillus niger. (Inhibition zone $22 \mathrm{~mm}$ ).Minimum Inhibitory Concentration (MIC) for extract ranged from $25 \mathrm{mg} / \mathrm{l}$ to $50 \mathrm{mg} / \mathrm{l}$. It is also clear that plant extract have minimum MIC for Candida albicans with $12 \mathrm{~mm}$ but in case of Aspergillus niger with $11 \mathrm{~mm}$..Antifungal activity Olea glandulifera, against two fungal strain- Candida albicans and Aspergillus niger is summarized in the table No.3(Fig-C and D)

TABLE 3: MEAN INHIBITION ZONE DIAMETER OBTAINED BY LOADED DISC (Olea glandulifera) WITH 5 mg EXTRACT DISSOLVED AGAINST DIFFERENT FUNGAL STRAIN

\begin{tabular}{|l|l|l|l|l|}
\hline \multirow{2}{*}{$\begin{array}{l}\text { Different concentration } \\
\text { of plant extract(mg/l) }\end{array}$} & \multicolumn{4}{|l|}{ Test Fungi } \\
\cline { 2 - 5 } & Candida albicans & Aspergillus niger \\
\cline { 2 - 5 } & Status & ZD(mm) SEM & Status & ZD(mm) SEM \\
\hline 200 & A & $24 \pm 1.247$ & A & $21 \pm 1.247$ \\
\hline 100 & A & $21 \pm 2.045$ & A & $20 \pm 0.816$ \\
\hline 50 & A & $18 \pm 1.690$ & N & $16 \pm 1.699$ \\
\hline 25 & A & $12 \pm 0.9428$ & - & - \\
\hline 12.5 & - & - & - & - \\
\hline
\end{tabular}

Key to tables:

$\begin{array}{ll}\text { Symbole } & \text { Meaning } \\ \text { A } & \text { active } \\ \mathbf{N} & \text { Non Active } \\ \text { ZD } & \text { Zone diameter } \\ (-) & \text { No effect } \\ \text { SEM } & \text { Standard error of Mean }\end{array}$

It is clear that, the plant extract shows antifungal assay when the concentration of dichloromethane was increased. It is also clear that plant extract have maximum antifungal activity against Candida albicans( inhibition zone $24 \mathrm{~mm}$ ) and Aspergillus niger. (Inhibition zone $21 \mathrm{~mm}$ ). Minimum Inhibitory Concentration (MIC) for extract ranged from $25 \mathrm{mg} / \mathrm{l}$ to $50 \mathrm{mg} / \mathrm{l}$. It is also clear that plant extract have minimum MIC for Candida albicans with $12 \mathrm{~mm}$ but in case of Aspergillus niger with $16 \mathrm{~mm}$. In is clear from this study that dichloromethane extract of Olea Species, possessed antifungal activity. This further supports the traditional medicinal uses of this plant for the various infectious diseases caused by fungi. Result of antifungal activity shows that higher concentration of dichloromethane extract was more effective against fungi. Although individual phenolic compound in Olive extract Imay show strong in vitro activities, the antioxidant and antimicrobial activities of combined phenolics showed similar or better effects than the individual phenolics (Lee and Lee, 2010).Owen et al, 2003, further supported that extracts may be beneficial than isolated constituents since a bioactive components can change its properties in the presence of other compounds present in the extract. Certainly the chemical composition of the Olive extracts impacted the antimicrobial effects observed. (Denyer, 1998). In fact the mode of action of phenolics has been shown to be concentration dependent (Furneri et al, 2002).

\section{REFERENCES:}

[1] Amer S, Aly MM, Sabbagh S, 2006. Biocontrol of dermatophytes using some plant extracts and actinomycetes filtrates. Egyptian J. Biotechnol., 330-315

[2] Aziz N.H, Farag S.E., Mousa L.A., Abo-Zaid M.A. (1998). Comparative antibacterial and antifungal effects of some phenolic compounds. Microbios, 93: 43-54

[3] Battinelli L; Daniele C; Cristiani G; Mazzanti G., 2006. In vitro antifungal and anti-elastase activity of some aliphatic aldehydefrom Olea europaea L. fruit.Phytomedicine,13(8): 558-563.

[4] Benavente- Garcia O., Castillo J., Lorente J., Ortuno A., Del Rio J.A. (2000). Antioxidant activity of phenolics extracted from Olea europaea L. Leaves. Food Chem. 68: 457- 462.

[5] Chopra, R.N., Nayar, S.L. and Chopra, 1.C. (1956), Glossary of Indian `Medipinai Plants, C.S.1.R., New Delhi, 1-329

[6] Cruiskshank R., J.P. Duguid, B.P. Marmion and R.H. Swain (1975).Medicinal Microbiology,12 ${ }^{\text {th }}$ Edition Churchill Livingstone. Edinburgh.

[7] Denyer SP; Stewart GSA B. Int. Biodetect, Biodeg; 1998, 41, 261-268.

[8] Furneri PM; Marino A; Saija A; Uccella N and Bissignano G. 2002, Int. J. Antimicrob, 20, 293-296.

[9] Gourama H., Bullerman L.B. (1987). Effect of oleuropein on growth and aflatoxin production by Aspergillus parasiticus. Lebensm. Wiss U. Technol., 20: 226-228. 
[10] Khayyal M.T. EI- Ghazaly, M.A. Abdallah, D.M. Nassar, N.N. Oppanyi, S.N., Kreuter, M.H. (2002). Blood pressure lowering effect of an olive leaf extract (Ilea eurppeae) in L- NAME induced hyperetension in rats. Arzneimittelforshung, 52 (11): 797802.

[11] Lee OH and Lee BY. Bio. Tech; 2010, 101, 3751-3754.

[12] Murray PR; Baron EJ; Pfaller MA; Tenover FC and Yolke RH. In Manual of Clinical Biology, $7^{\text {th }}$ ed, Washiington, DC:ASM, 1995,1773 .

[13] Owen RW, Haubner R, Mier W ; Giacosa A; Hull WE; Spiegelhalder B and Bartsch H. 2003, Food Chem. Taxicol, 41, 703-717.

[14] Pereira, AP, Ferreira, ICFR; Marcelino, F; Valentao, P; Andrade, PB; Seabra R; Estevinho L; Bento A and Pereira, PA, Molecules, 2007,12,1153-1162.

[15] Scott, A.C. (1989). Laboratory control of antimicrobial therapy. In: practical medical Microbiology. (Eds. J.G. Collee, J.P. Duquid, A.G. Fraser and B.P. Marmion) $13^{\text {th }}$ Edn. Churchill Livingetone. Edinburg.

[16] Sousa A. Ferreira I.C.F.R., Calhelha R., Andrade P.B., Valentao P. Sebabra R. Estevinho L, Bento A., Pereira J.A. (2006). Phenolics and antimicrobial activity of traditional stoned table olives alcaparra Bioorg. Med. Chem. (In press).

[17] Valeria FM, Preve L, Tullio V, 1996. Fungi responsible for skin mycoses in Turin (Italy). Mycoses, 39: 141-150.

[18] Yigit AS., Sahan Y. Korukluoglu M. (2001). Antimicrobial substnces found in olive leaves and olive. 2nd International Altinouluk Antandros Olive Busines Symposium, Turkey, pp. 139- 147.

[19] Zarzuelo A. (1991). Vasodilator effect of olive leaf. Planta Med., 57: 417- 419.
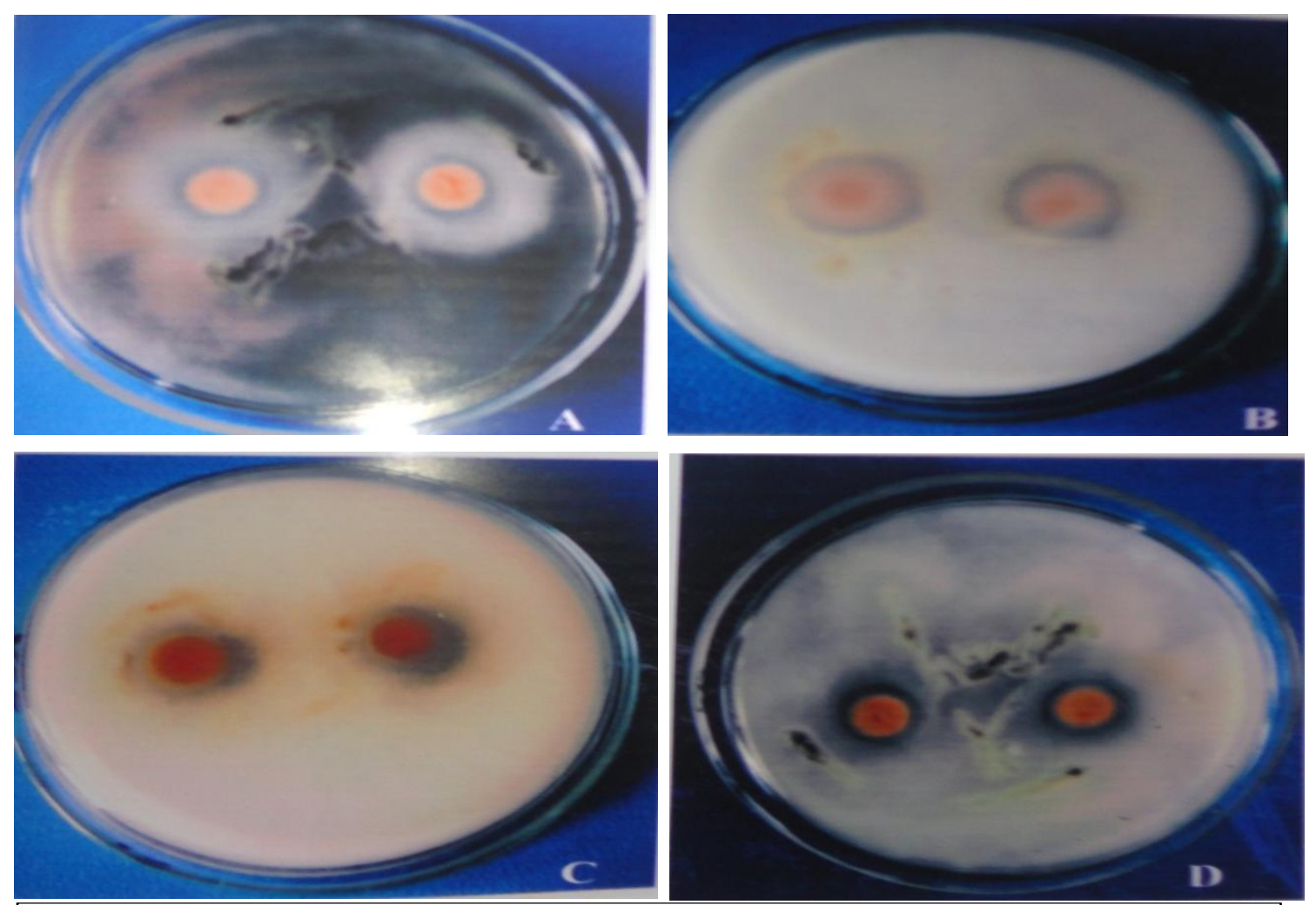
A. Effect of Olea cuspidata leaves on Aspergillus niger
B. Effect of Olea cuspidata leaves on Candida albicans
C. Effect of Olea glandulifera leaves on Candida albicans
D. Effect of Olea glandulifera leaves on Aspergillus niger 